\title{
Idiopathic polyneuritis: serial studies of nerve and immune functions ${ }^{1}$
}

\author{
MICHAEL P. McQUILLEN \\ From the Department of Neurology, University of Kentucky Medical Center, Lexington, \\ Kentucky 40506, U.S.A.
}

SUMMARY The clinical features of idiopathic polyneuritis in 22 patients admitted to the University of Kentucky Medical Center between July 1965 and June 1970 are described. Serial studies of peripheral nerve function in 12 patients followed to clinical recovery showed changes in nerve conduction velocity, distal motor latency, and/or muscle action potential amplitude. Six children and one adult, showing a change in all three parameters, exhibited a strong correlation between the degree of slowing and the shortness of their illness. Assessment of immune status, by quantitative measurement of cerebrospinal fluid immunoglobulin G(11 patients) and by the degree of lymphocyte transformation on exposure to specific brain protein and/or a homogenate of sciatic nerve (10 patients), bore no consistent relation to the severity or course of the illness. A double-blind trial of short-term, high dose adrenocorticotrophic hormone has yielded no valid evidence to date for or against the effectiveness of such therapy in this illness.

The natural history of idiopathic polyneuritis has been a subject of controversy since the earliest descriptions of this illness (Landry, 1859; Guillain Barré, and Strohl, 1916; Wiederholt, Mulder, and Lambert, 1964). Some divide the disease into various clinical categories which reflect the duration and severity of illness in their patients (Ravn, 1967). Others have called for strict diagnostic criteria which, if violated, imply possibly a separate illness, certainly one which follows a different course (Osler and Sidell, 1960). Still others find no correlation between persistence of deficit and age, speed of progression, objective sensory loss, cerebrospinal fluid pleocytosis, steroid therapy, or nerve conduction studies done many years after the onset of symptoms (Pleasure, Lovelace, and Duvoisin, 1968). It is important to settle this question, if for no other reason than to evaluate various forms of therapy. This will be a difficult task, as long as the cause of the disease remains obscure. Recent and convincing pathological evidence supports the concept that whatever the precipitating cause, the common pathological denominator is an intense immune response (Asbury, Arnason, and Adams, 1969).

This report deals with a group of 22 patients with

${ }^{1}$ Supported in part by research grants from the American Cancer Society, Kentucky Division. idiopathic polyneuritis, followed at the University of Kentucky Medical Center during the five years since its Department of Neurology was started. Twelve of the patients were followed to clinical recovery with serial studies of peripheral nerve function. Two patterns of change in nerve function were observed. Patients who followed one pattern showed a high correlation between slowing of nerve conduction velocity and brevity of illness. Immune factors were studied in 13 patients, to assess the incidence and specificity of such factors and the degree of their correlation with the course and severity of the polyneuritis.

METHODS

During the period from 1 July 1965 through 30 June 1970, 23 patients were admitted to the Medical Center with a diagnosis of idiopathic polyneuritis. One of these patients is not included in this study - a child, seen at the age of 2 for slow motor development, who had a normal cerebrospinal (CSF) protein level $(16 \mathrm{mg} / 100 \mathrm{ml}$ ) despite a slow motor nerve conduction velocity $(11 \mathrm{~m} / \mathrm{sec})$ in his ulnar nerve. He was eliminated from the study not only because his CSF protein should have been elevated if he had idiopathic polyneuritis (Chambers and MacDermot, 1957), but also because nothing is known of the onset or subsequent clinical course of his problem.

Therefore, the patient group chosen for study comprises 22 subjects-eight adults and 14 children. During 
the five year period in question, there were 1,614 admissions to the adult neurology service $(13,385$ to adult medical beds in general), and 6,633 admissions to the children's service. This amounts to an incidence of 5 per 1,000 adult neurology admissions ( 0.6 per 1,000 adult medical admissions), and $2 \cdot 1$ per 1,000 paediatric admissions-or an overall incidence of $1 \cdot 1$ per 1,000 admissions.

Studies were made of peripheral nerve function in the patient group by standard methods previously described (McQuillen and Gorin, 1969). Where possible, these studies included measurement of motor and mixed nerve conduction velocities in an ulnar nerve; of distal latency-that is, the time from stimulus at the wrist to onset of the grouped muscle action potential in the handand of grouped muscle action potential amplitude. An ulnar nerve was chosen for study, in order that changes during serial studies might be compared with the normal variation known to occur in its function (McQuillen and Gorin, 1969). Random studies of other nerves (peroneal and tibial) did not yield data that were qualitatively different, even when involvement was more prominent in the lower extremities.

The motor nerve conduction velocities cited in this paper are modal velocities. This average velocity was felt to be more reliable for comparison in serial studies, since the amplitude of the evoked muscle action potential was often quite small. When the amplitude was small, it was difficult to judge accurately the time from stimulus $\mathbb{\mathscr { Q }}$ to onset of the response, particularly with distal stimulation.

Quantitative measurement of immunoglobulin contente in serum and CSF was performed by the single radial 0 immunodiffusion method of Mancini, Carbonara, and Heremans (1965). Lymphocyte transformation was studied by culture of lymphocytes obtained from heparinized blood samples. The culture period was five days. Each series consisted of quadruplicate cultures containing approximately $1.5 \times 10^{6}$ cells. Saline solution was added $\stackrel{\mathcal{S}}{\rightarrow}$ to control cultures. Either a homogenate of human sciatic $\overline{0}$ nerve or specific brain protein was added as antigen $\bar{C}$ to test cultures. Twelve hours before the end of the culture $\overline{\bar{c}}$. period $4 \mu \mathrm{c}$ tritiated thymidine was added to each $\vec{\nabla}$ culture. At the end of the culture period the cells were $\varrho$ washed to eliminate unincorporated isotope. The activity $\approx$ of incorporated isotope was determined in a scintillation $\vec{\circ}$ counter. Disintegrations per minute were determined for each culture. Stimulation (or depression) is expressed as a $\vec{\omega}$ per cent of controls.

\section{RESULTS}

CLINICAL FEATURES The characteristics of the patient $\stackrel{\omega}{f}$ group are outlined in Table 1 . The categories are those of Ravn (1967). They are used because the duration of illness is felt to differ from one categor

TABLE 1

CLINICAL FEATURES

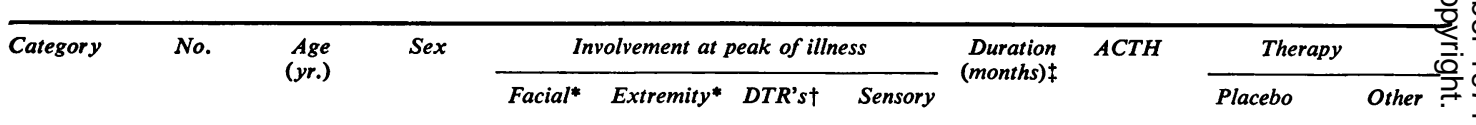

\begin{tabular}{|c|c|c|c|c|c|c|c|c|c|c|c|}
\hline I & $\begin{array}{l}1 \\
2 \\
3 \\
4 \\
5 \\
6\end{array}$ & $\begin{array}{l}47 \\
39 \\
64 \\
1 \cdot 8 \\
6 \\
8\end{array}$ & $\begin{array}{l}\mathbf{M} \\
\mathbf{M} \\
\mathbf{M} \\
\mathbf{M} \\
\mathbf{M} \\
\mathbf{M}\end{array}$ & $\begin{array}{c}++ \\
0 \\
0 \\
++++ \\
++ \\
++\end{array}$ & $\begin{array}{c}++ \\
++++ \\
++++ \\
++++ \\
++++ \\
+++\end{array}$ & $\begin{array}{c}0 \\
0 \\
0 \\
0 \\
0 \\
+ \text { arms } \\
0 \text { legs }\end{array}$ & $\begin{array}{c}+++ \\
+ \\
0 \\
0 \\
0 \\
0\end{array}$ & $\begin{array}{c}2 \\
5 \\
24 \\
4 \text { (died) } \\
(5+)\end{array}$ & $\begin{array}{l}\mathbf{x} \\
\mathbf{x} \\
\mathbf{x} \\
\mathbf{x}\end{array}$ & & $\begin{array}{l}\text { Prednisone } \\
\text { Prednisone } \\
\text { INH }\end{array}$ \\
\hline II & $\begin{array}{r}7 \\
8 \\
9 \\
10 \\
11 \\
12 \\
13 \\
14 \\
15\end{array}$ & $\begin{array}{r}42 \\
55 \\
5 \\
5 \\
16 \\
7 \\
8 \\
14 \\
11\end{array}$ & $\begin{array}{l}\mathbf{M} \\
\mathbf{F} \\
\mathbf{F} \\
\mathbf{F} \\
\mathbf{F} \\
\mathbf{F} \\
\mathbf{F} \\
\mathbf{M} \\
\mathbf{F}\end{array}$ & $\begin{array}{c}+ \\
+ \\
++ \\
+ \\
+ \\
+ \\
+ \\
+ \\
+\end{array}$ & $\begin{array}{c}++ \\
+++ \\
++ \\
++ \\
+++ \\
++ \\
++ \\
++ \\
++ \text { arms } \\
++++ \\
\text { legs } \\
++ \\
++ \\
++ \\
+++\end{array}$ & $\begin{array}{c}+ \\
0 \\
0 \\
0 \\
0 \\
0 \\
0 \\
++ \\
+ \text { arms } \\
0 \text { legs } \\
0 \\
0 \\
0 \\
0 \\
0\end{array}$ & $\begin{array}{l}0 \\
0 \\
0 \\
0 \\
+ \\
0 \\
0 \\
+ \\
0\end{array}$ & $\begin{array}{l}10 \\
\\
2 \\
3 \cdot 5 \\
7 \\
8 \\
8 \\
11 \\
18\end{array}$ & $\mathbf{x}$ & $\mathbf{x}$ & INH \\
\hline III & $\begin{array}{l}20 \\
21 \\
22\end{array}$ & $\begin{array}{l}45 \\
38 \\
73\end{array}$ & $\begin{array}{l}\mathbf{M} \\
\mathbf{M} \\
\mathbf{M}\end{array}$ & $\begin{array}{l}0 \\
0\end{array}$ & $\begin{array}{c}++ \\
\text { legs only } \\
+++ \\
++++\end{array}$ & $\begin{array}{c}++ \text { arms } \\
0 \text { legs } \\
0 \\
+\end{array}$ & $\begin{array}{c}0 \\
++ \\
0\end{array}$ & $\begin{array}{l}5 \\
8\end{array}$ & & $\mathbf{x}$ & EDTA \\
\hline
\end{tabular}

$* 0$ = no involvement; $+=$ mild; $++=$ moderate; $+++=$ severe; $++++=$ no function.

t0 = absent; $+=$ hypoactive; $++=$ normal.

$\ddagger$ From peak weakness to recovery; patient lost to follow-up if no information is given; patient 5 is still recovering function. 
to another, even in untreated patients. Each category is subdivided further by age, since idiopathic polyneuritis may be a milder disease in childhood than in adult life (Markland and Riley, 1967; Asbury et al., 1969; Paulson, 1970).

The most seriously ill patients are in category $I$. All patients in this category required tracheostomy and assisted respiration. Patients 2 and 3 could still swallow at the peak of their illness, but all others in this category required a nasogastric tube for nourishment. Patient 1 had a total external ophthalmoplegia, in addition to his other troubles.

Category II consists of patients with milder involvement of bulbar and spinal nerves, not requiring mechanical assistance to breathe or swallow. Children predominated in this category. Patients 18 and 19 had mild dysphagia and jaw weakness but could swallow effectively. Patient 8 had mild respiratory weakness but did not require assisted respiration.

In category III are patients with no bulbar weakness. Patient 22 had the onset of quadriparesis within less than a day, as did patient 3 in category I. Both of these patients had suggestively upgoing toes, during the acute phase of their illness only. Both had hyponatraemia that responded to severe restriction of fluids, much in the fashion of the syndrome of inappropriate antidiuretic hormone secretion (Posner, Ertel, Kossman, and Scheinberg, 1967). Patient 3 developed a persistent cardiac arrhythmia that disappeared only when he was given high doses of prednisone. He had electrocardiographic changes interpreted by a cardiac consultant as evidence for a myocarditis.

Deep tendon reflexes were elicited despite the presence of weakness in two adults and three children. A mild stocking-glove hypalgesia was present in six patients. Moderate sensory loss was observed in patient 21 , whose illness began a week after exposure to a concentrate of malathion. He was treated with a chelating agent because of a questionable increase in urinary lead excretion. There was no change in his clinical state and no increase in lead excretion during therapy. Marked vibratory sense loss was observed in patient 1 at the peak of his illness. The distribution of weakness in the extremities did not follow any standard pattern. It was more prominent proximally in 11 patients (nos. 1, 3, 7, 9-11, 16-19, and 21); of equal prominence proximally and distally in six patients (nos. 4, 5, 8, 12, and 20); and more prominent distally in the remaining five patients.

THERAPY Before March 1968, all patients with lifethreatening weakness - that is, in category I-were treated with aqueous adrenocorticotrophic hormone
(ACTH) or prednisone in high dosage, in view of the opinion that steroid therapy is of benefit in idiopathic polyneuritis (Heller and DeJong, 1963). Patient 6 was not given steroids since he had been taking isonicotinic acid hydrazide (INH) for two years before the onset of his polyneuritis. The INH was prescribed because of a family history of tuberculosis and a personal history of skin test conversion.

Beginning in March 1968, a random, doubleblind trial was started to compare the effect of ACTH (1,000 units intramuscularly over a seven to 10 day period) with that of a placebo. Patient 3 in category I was the first subject to enter this trial. $\mathrm{He}$ developed hyponatraemia after two days of therapy. The code was broken, it was found that he was receiving $\mathrm{ACTH}$, and this was stopped. Hyponatraemia improved on restriction of fluids. Three weeks later he developed a persistent cardiac arrhythmia thought to be due to a myocarditis. The arrhythmia disappeared only after he was given high doses of prednisone ( $80 \mathrm{mg}$ by mouth per day). Because of this experience, the trial has been limited since then to patients in categories II and III. Separate random groups for children and adults were established. The two children (patients 9 and 12) who received ACTH during the trial had a relatively brief illness, of two to eight months, respectively. The duration of illness in children (patients 10 and 15 ) and adults (patients 7 and 20) receiving placebo ranged from 3.5 to 18 months.

Plasma cortisol levels and/or urinary steroid output were followed in six patients (nos. 1, 7, 9, 10, 12, and 20). Cortisol levels rose proportionately higher than did steroid output in the one patient (no. 9) in whom both sorts of determinations were done. These studies correctly identified the patients receiving ACTH, by virtue of a rise in cortisol level or steroid output, in all but one instance (patient 12). Despite the fact that this patient received ACTH she showed no significant rise in 17 -ketosteroid or 17-ketogenic steroid excretion in the urine. The apparent failure to respond to ACTH may be an error of measurement, since plasma cortisol levels (if obtained) might have shown a rise not mirrored by changes in urinary steroid excretion. Such findings would indicate rapid metabolism or inactivation of ACTH, and in this way could be related to the duration of her illness. Patient 12 was given INH during and after ACTH treatment, in view of a personal history of pulmonary tuberculosis four years before the onset of her polyneuritis. No clinical activation of the tuberculosis occurred.

STUDIES OF PERIPHERAL NERVE FUNCTION Studies of peripheral nerve function were obtained in all but 
two patients (nos. 8 and 19). Selected data from remaining 20 patients are recorded in Table 2 . Nine patients had a modal motor nerve conduction velocity (modal NCV) within normal range for our laboratory at the time of first study. Eight patients showed an increase in distal latency. Only two patients had a muscle action potential of normal amplitude. In two patients (nos. 4 and 5) a muscle action potential could not be recorded, although a nerve action potential was seen proximally with stimulation of mixed nerve distally. Children showed the clearest deviation from normal in all parameters. However, there was considerable overlap among clinical and age categories.

Six adults and six children were followed to clinical recovery with serial studies. Two patterns of nerve function were observed. In pattern one, modal NCV remained nearly within a normal range during the course of the illness with the major change noticed in the amplitude of the evoked potential (Fig. 1) or in distal latency. In pattern two a marked change was seen in all parameters (Fig. 2). Peak abnormalities were observed from $7 \cdot 5$ weeks before to 10 weeks after the point of maximal weakness was reached. Recovery of normal function paralleled clinical recovery, although it lagged behind return to normal strength. Deep tendon reflexes returned to normal at essentially the same time as peripheral $\mathbb{D}$ nerve function. Again, children showed the most severe changes. Mean modal NCV was $17 \cdot 3 \pm 9 \cdot 6 \stackrel{\text { ? }}{\complement}$ $(\mathrm{m} / \mathrm{sec})$ in children and $40.4 \pm 11.8 \mathrm{~m} / \mathrm{sec}$ in adults, 0 at the time of slowest study. Mean modal NCV 0 was slower in pattern two $(18.5 \pm 9.3 \mathrm{~m} / \mathrm{sec})$ than in pattern one $(43.9 \pm 10 \mathrm{~m} / \mathrm{sec})$, at this time, also.

Attempts to find a correlation between changes in peripheral nerve function and clinical course were productive in pattern two only. In this instance there is a strong correlation between the degree of slowing $\overrightarrow{0}$ of modal NCV and the duration of the illness (Fig. 3). 을 The slowest conduction velocities were associated $\overline{\bar{\omega}}$ with the shortest clinical courses. Among the $12 \mathbb{\Phi}$ patients followed to clinical recovery with serial studies, all six children and one adult (patient 21) followed pattern two.

CEREBROSPINAL FLUID (CSF) FINDINGS Spinal punc- $\stackrel{\omega}{\mathscr{\omega}}$ ture was performed 47 times on the 22 patients. All but five punctures were made at the peak of weakness \pm one month. Total CSF protein ranged $\omega$ from 7 to $300 \mathrm{mg} / 100 \mathrm{ml}$.

Serial studies were done on six adults and eigh children. No consistent pattern of change was oto served. Three children showed a decrease in totâ 을 protein before peak weakness. One child and three

TABLE 2

STUDIES OF PERIPHERAL NERVE FUNCTION

\begin{tabular}{|c|c|c|c|c|c|c|c|c|c|c|c|c|c|c|}
\hline \multirow[t]{3}{*}{ Category } & \multirow[t]{3}{*}{ No. } & \multicolumn{6}{|c|}{ First study } & \multicolumn{7}{|c|}{ Study showing greatest abnormality } \\
\hline & & \multirow{2}{*}{$\begin{array}{l}\text { Time } \\
\text { (days) }\end{array}$} & \multirow[t]{2}{*}{$V_{p} \dagger$} & \multirow[t]{2}{*}{$V_{m} \dagger$} & \multirow{2}{*}{$\begin{array}{r}\text { Distal } \\
\text { latency } \\
\text { (msec) }\end{array}$} & \multicolumn{2}{|c|}{ Map Amp $(m V)$} & \multicolumn{2}{|c|}{ Time +} & \multirow[t]{2}{*}{$V_{p} \dagger$} & \multirow[t]{2}{*}{$V_{m} \dagger$} & \multirow{2}{*}{$\begin{array}{c}\text { Distal } \\
\text { latency } \\
\text { (msec) }\end{array}$} & \multicolumn{2}{|c|}{ Map Amp $(m V)$} \\
\hline & & & & & & Elbow & Wrist & $\begin{array}{c}\text { To study } \\
\quad(w k)\end{array}$ & $\begin{array}{l}\text { To recov- } \\
\text { ery (mos) }\end{array}$ & & & & Elbow & Wrist \\
\hline $\mathbf{l}$ & $\begin{array}{l}1 \\
2 \\
3 \\
4 \\
5 \\
6\end{array}$ & $\begin{array}{r}2 \\
5 \\
8 \\
57 \\
4 \\
26\end{array}$ & $\begin{array}{c}57 \cdot 8 \\
46 \cdot 3 \\
37 \cdot 8 \\
- \\
- \\
6 \cdot 8\end{array}$ & $\begin{array}{c}53 \cdot 8 \\
49 \cdot 6 \\
58 \cdot 2 \\
38 \cdot 3 \\
47 \\
-\end{array}$ & $\begin{array}{c}2 \cdot 7 \\
4 \cdot 4 \\
2 \cdot 3 \\
- \\
-\end{array}$ & $\begin{array}{l}3.4 \\
1.7 \\
0.04 \\
- \\
\overline{0}\end{array}$ & $\begin{array}{l}5 \\
2 \cdot 1 \\
0.07 \\
- \\
\overline{0.5}\end{array}$ & $\begin{array}{l}1 \\
2 \\
3\end{array}$ & $\begin{array}{c}2 \\
5 \\
24 \\
4 \text { (died) } \\
(5+)\end{array}$ & $\begin{array}{l}52 \cdot 3 \\
35 \cdot 9 \\
34 \cdot 4\end{array}$ & $\frac{52 \cdot 2}{56 \cdot 6}$ & $\begin{array}{r}2 \cdot 8 \\
18 \cdot 4 \\
5 \cdot 5\end{array}$ & $\begin{array}{l}3 \\
0.9 \\
0.05\end{array}$ & $\begin{array}{l}3 \cdot 4 \\
1.4 \\
0.03\end{array}$ \\
\hline II & $\begin{array}{r}7 \\
9 \\
10 \\
11 \\
12 \\
13 \\
14 \\
15 \\
16 \\
17 \\
18\end{array}$ & $\begin{array}{r}14 \\
21 \\
8 \\
21 \\
7 \\
2 \\
5 \\
3 \\
72 \\
17\end{array}$ & $\begin{array}{c}49 \cdot 1 \\
11 \cdot 1 \\
9 \cdot 8 \\
25 \\
22 \cdot 8 \\
50 \\
49 \cdot 6 \\
48 \cdot 1 \\
36 \cdot 4 \\
11 \\
21 \cdot 7\end{array}$ & $\begin{array}{c}-\overline{60 \cdot 5} \\
62 \cdot 5 \\
-\end{array}$ & $\begin{array}{c}2 \cdot 9 \\
11 \cdot 5 \\
5 \cdot 2 \\
13 \\
8 \cdot 5 \\
1 \cdot 5 \\
3 \cdot 2 \\
2 \cdot 1 \\
2 \cdot 6 \\
4 \cdot 2\end{array}$ & $\begin{array}{l}3 \cdot 8 \\
1 \cdot 7 \\
1 \cdot 5 \\
0 \cdot 4 \\
1 \cdot 8 \\
0 \cdot 03 \\
3 \cdot 1 \\
0 \cdot 1 \\
9 \cdot 9 \\
0.5\end{array}$ & $\begin{array}{l}3.9 \\
3 \cdot 1 \\
3.5 \\
0.6 \\
1.9 \\
0.03 \\
6.8 \\
0.6 \\
9.5 \\
1.4\end{array}$ & $\begin{array}{c}2 \\
-7 \cdot 5 \\
1 \\
7 \\
2 \cdot 5 \\
1 \\
2\end{array}$ & $\begin{array}{c}10 \\
2 \\
3 \cdot 5 \\
7 \\
8 \\
8 \\
11 \\
18\end{array}$ & $\begin{array}{r}59.4 \\
10.6 \\
6.4 \\
12.5 \\
16.9 \\
\\
28 \\
34.8\end{array}$ & $\begin{array}{l}52 \cdot 5 \\
- \\
- \\
33 \cdot 8 \\
60 \\
55\end{array}$ & $\begin{array}{r}3.4 \\
11 \cdot 2 \\
9.5 \\
19 \cdot 2 \\
5.3 \\
2.2 \\
1 \cdot 8\end{array}$ & $\begin{array}{l}3 \cdot 2 \\
1 \cdot 3 \\
1 \cdot 6 \\
0 \cdot 7 \\
2 \cdot 5 \\
\\
1 \cdot 1 \\
0 \cdot 1\end{array}$ & $\begin{array}{l}3 \cdot 8 \\
1.7 \\
2.8 \\
1.6 \\
2.8 \\
\\
2.2 \\
0.2\end{array}$ \\
\hline III & $\begin{array}{l}20 \\
21 \\
22\end{array}$ & $\begin{array}{r}107 \\
41 \\
5\end{array}$ & $\begin{array}{l}40 \cdot 1 \\
29 \cdot 1 \\
42\end{array}$ & $\begin{array}{l}42 \cdot 6 \\
40 \cdot 6\end{array}$ & $\begin{array}{l}3 \\
4 \cdot 7 \\
2 \cdot 7\end{array}$ & $\begin{array}{r}19.9 \\
0.2 \\
1.4\end{array}$ & $\begin{array}{r}15 \cdot 3 \\
1 \cdot 3 \\
5 \cdot 8\end{array}$ & $\begin{array}{r}10 \\
10 \\
4\end{array}$ & $\begin{array}{l}5 \\
8\end{array}$ & $\begin{array}{l}37 \cdot 7 \\
20 \cdot 4 \\
42 \cdot 6\end{array}$ & $\frac{43}{69 \cdot 7}$ & $\begin{array}{l}2 \cdot 6 \\
6 \\
3 \cdot 2\end{array}$ & $\begin{array}{l}9 \cdot 5 \\
1 \\
1 \cdot 2\end{array}$ & $\begin{array}{r}16 \cdot 1 \\
3 \cdot 5 \\
2 \cdot 4\end{array}$ \\
\hline
\end{tabular}

* From onset of symptoms to first study.

$\dagger$ In metres per second; $-=$ action potential looked for but not seen; normal range: $V_{p}=38 \cdot 1-64 \cdot 3 ; V_{m}=48 \cdot 7-61 \cdot 4$.

$\ddagger$ From peak of weakness to time of study or to recovery. 

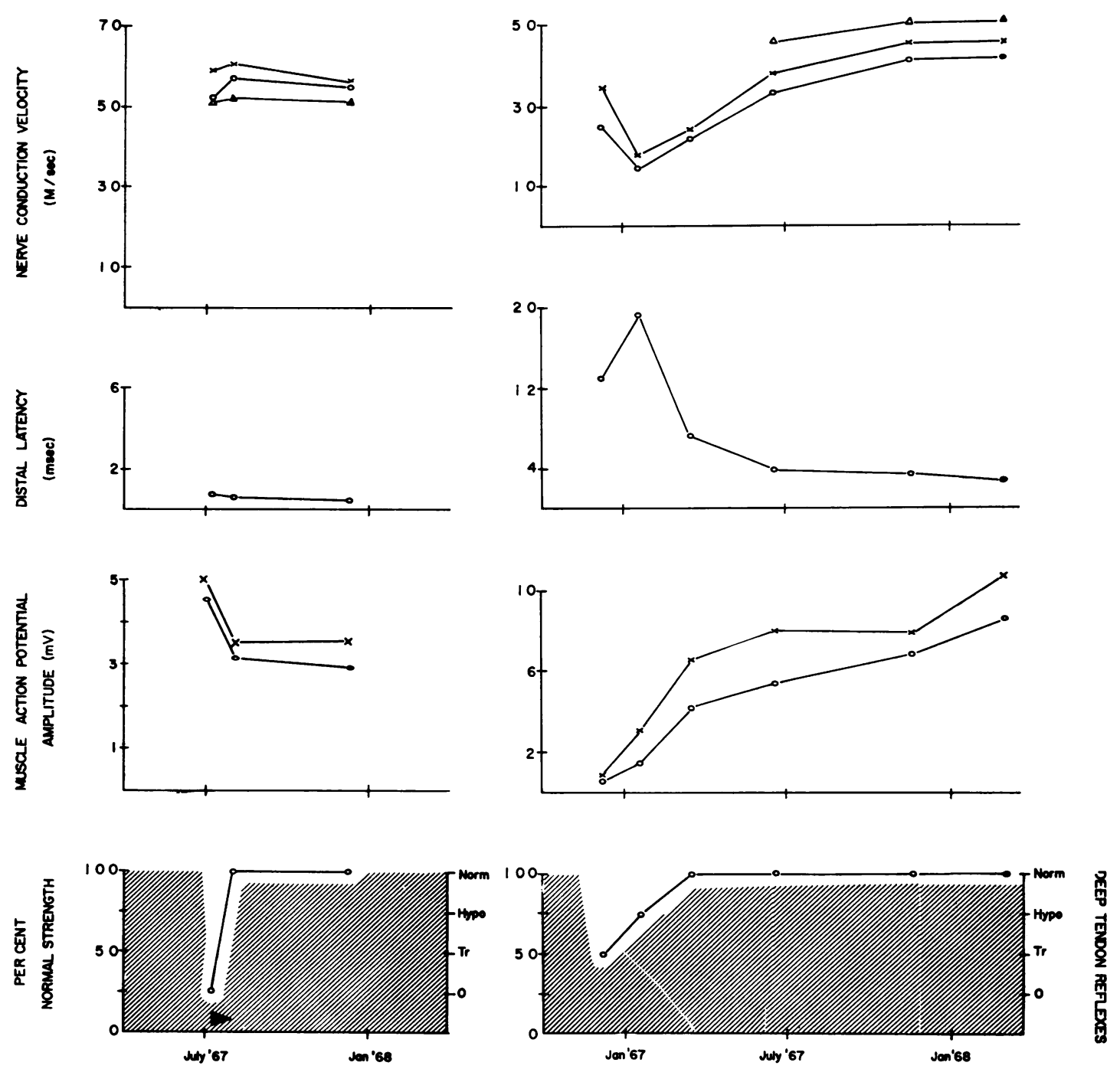

FIG. 1.

FIG. 2 .

FIGS. 1 and 2. Pattern of change in nerve function. Fig. 1: pattern one (patient 1); Fig. 2: pattern two (patient 11). In each Figure, the uppermost segment is ulnar nerve conduction velocity: $x-x, V o ; V p ; \triangle-\triangle, V m ;$ the second segment is distal latency; the third segment is muscle action potential amplitude in the hypothenar eminence after stimulation of the ulnar nerve at the elbow $(0)$ and wrist $(x)$; the bottom segment is the clinical course (shaded area, with reference to ordinate at left $)$ and deep tendon reflexes (o-o, with reference to ordinate at right). The black triangle in Fig. 1 represents ACTH therapy. Abscissa, time.

adults showed an increase after peak weakness. Four children showed an increase followed by a decrease after peak weakness.

Quantitative measurement of CSF immunoglobulin G (IgG) content was obtained in seven children and four adults (Table 3). Paired determinations were done in four children and three adults.
IgG amounted to less than $10 \%$ of total protein on six occasions; more than $20 \%$ on four occasions; and between 10 and $20 \%$ on seven occasions. No consistent relation to peak weakness was noticed on single studies. No consistent change in level with reference to peak weakness was observed.

Quantitative determination of serum immuno- 


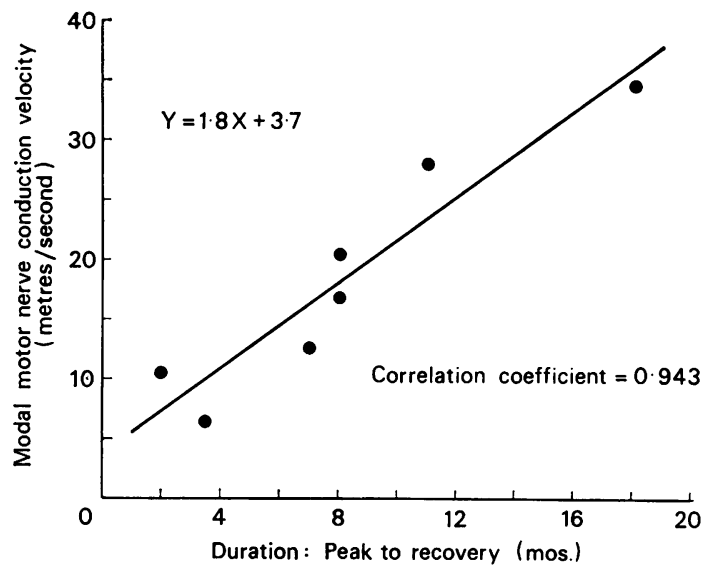

FIG. 3. Correlation between slowest ulnar model motor nerve conduction velocity (ordinate, in metres per second) and duration of illness from peak weakness to recovery (abscissa, in months), in pattern two.

globulins of nine patients generally showed a normal content of IgG, IgA and IgM for age (Table 3). Again, no consistent change with reference to peak weakness was observed.

LYMPHOCYTE TRANSFORMATION The ability of an antigen to alter the rate of transformation of lympho- $\overline{\mathbb{D}}$ cytes in cell culture was studied in 10 patients (Table 4). Serial studies were done on three patients. Four patients were receiving steroids at the time of study. All studies were obtained at or after the peak 0 of weakness.

A significant increase-that is, $\bar{x}-2 \mathrm{SD}>100 \%$ in lymphocyte transformation rate was noted in four patients. In patient 20 , the increase occurred on exposure to specific brain protein, as well as on $\overrightarrow{\vec{F}}$ exposure to homologous peripheral nerve. Onepatient showed a decrease in enhanced transformation, while receiving ACTH. Two other patients, on $\overline{\bar{m}}$ ACTH at the time of study, showed no enhanced $\overrightarrow{\mathbb{D}}$ transformation. The use of prednisone did not $\stackrel{\circ}{\circ}$ appear to alter the marked increase in transformation ${ }^{\circ}$ noted in patient 3 . Patient 7 , who showed no signifi- $\overrightarrow{0}$ cant change in transformation when homologous peripheral nerve was used an an antigen, exhibited a significant decrease in the rate of transformation when specific brain protein was used as the antigen

\section{DISCUSSION}

Although the total number of patients in this stufif is small with respect to other surveys of idiopathic응 polyneuritis there are some conclusions which seem warranted. In the first place, children with idiopatifico polyneuritis may have an illness as serious ang $\stackrel{\circ}{0}$

TABLE 3

IMMUNOGLOBULIN DETERMINATIONS

\begin{tabular}{|c|c|c|c|c|c|c|c|c|c|c|}
\hline \multirow[t]{2}{*}{ Category } & \multirow[t]{2}{*}{ No. } & \multicolumn{2}{|c|}{ Time* } & \multicolumn{3}{|c|}{ Cerebrospinal fluid } & \multicolumn{3}{|c|}{ Serum } & \multirow[t]{2}{*}{ Steroids } \\
\hline & & Before & After & $T P \dagger$ & $I g G \dagger$ & $I g G / T P \times 100$ & $I g G \dagger$ & $\operatorname{IgA\dagger }$ & $\operatorname{Ig} M+$ & \\
\hline \multirow[t]{2}{*}{$\mathbf{I}$} & 3 & & $\begin{array}{l}11 \\
56\end{array}$ & $\begin{array}{l}20 \\
26\end{array}$ & $\begin{array}{l}0.9 \\
5.6\end{array}$ & $\begin{array}{r}4 \cdot 5 \\
21 \cdot 5\end{array}$ & 1350 & 320 & 39 & $\mathbf{x}$ \\
\hline & 5 & 1 & 9 & $\begin{array}{r}28 \\
103\end{array}$ & $\begin{array}{l}0 \\
8 \cdot 4\end{array}$ & $\begin{array}{l}0 \\
8 \cdot 2\end{array}$ & 830 & 86 & 190 & $\begin{array}{l}x \\
x\end{array}$ \\
\hline II & $\begin{array}{r}7 \\
9 \\
10 \\
12 \\
14 \\
15 \\
16 \\
18\end{array}$ & $\begin{array}{r}65 \\
56 \\
9 \\
3\end{array}$ & $\begin{array}{r}6 \\
15 \\
2 \\
? \\
?\end{array}$ & $\begin{array}{r}116 \\
54 \\
40 \\
116 \\
86 \\
300 \\
24 \\
7 \\
46 \\
76\end{array}$ & $\begin{array}{l}17 \\
5 \cdot 1 \\
2 \cdot 9 \\
49 \\
10 \\
36 \\
11 \cdot 5 \\
3 \cdot 7 \\
5 \cdot 7 \\
7 \cdot 7\end{array}$ & $\begin{array}{r}14 \cdot 7 \\
9 \cdot 4 \\
7 \cdot 2 \\
42 \cdot 2 \\
11 \cdot 1 \\
12 \\
47 \cdot 9 \\
52 \cdot 9 \\
12 \cdot 4 \\
10 \cdot 1\end{array}$ & $\begin{array}{r}1850 \\
\\
900 \\
1300\end{array}$ & $\begin{array}{r}310 \\
90 \\
93\end{array}$ & $\begin{array}{r}170 \\
150 \\
82\end{array}$ & $\mathbf{x}$ \\
\hline III & $\begin{array}{l}20 \\
22\end{array}$ & & $\begin{array}{r}2 \\
17 \\
5 \\
33\end{array}$ & $\begin{array}{r}116 \\
116 \\
13 \\
20\end{array}$ & $\begin{array}{l}9 \cdot 7 \\
11 \\
1 \cdot 85 \\
4\end{array}$ & $\begin{array}{l}8 \cdot 4 \\
9 \cdot 5 \\
14 \cdot 2 \\
20\end{array}$ & $\begin{array}{l}1850 \\
1200 \\
3000\end{array}$ & $\begin{array}{r}180 \\
86 \\
560\end{array}$ & $\begin{array}{r}80 \\
190 \\
130\end{array}$ & \\
\hline
\end{tabular}

*In days, relative to peak weakness.

†In mg per $100 \mathrm{ml}$.

$\ddagger \mathrm{x}=\mathrm{ACTH}$ (prednisone for the second set of values on patient 3 ), being given at the time of study. 
TABLE 4

LYMPHOCYTE TRANSFORMATION

\begin{tabular}{|c|c|c|c|c|c|c|}
\hline \multirow[t]{2}{*}{ Category } & \multirow[t]{2}{*}{ No. } & \multicolumn{2}{|c|}{ Antigen ${ }^{*}$} & \multirow[t]{2}{*}{ Transformation $\dagger$} & \multicolumn{2}{|c|}{ Therapy } \\
\hline & & P.N. & B.P. & & $A C T H$ & Prednisone \\
\hline $\mathbf{I}$ & $\begin{array}{l}1 \\
3 \\
5\end{array}$ & $\begin{array}{l}\mathbf{x} \\
\mathbf{x} \\
\mathbf{x} \\
\mathbf{x}\end{array}$ & $\mathbf{x}$ & $\begin{array}{r}108 \pm 12 \\
250 \pm 17 \\
190 \pm 14 \\
184 \pm 19 \\
107 \pm 15 \\
84 \pm 15\end{array}$ & $\begin{array}{l}\mathbf{x} \\
\mathbf{x} \\
\mathbf{x}\end{array}$ & $\begin{array}{l}\mathbf{x} \\
\mathbf{x}\end{array}$ \\
\hline II & $\begin{array}{r}7 \\
9 \\
10 \\
12 \\
14 \\
15\end{array}$ & $\begin{array}{l}\mathbf{x} \\
\mathbf{x} \\
\\
\mathbf{x} \\
\mathbf{x} \\
\mathbf{x}\end{array}$ & $\begin{array}{l}\mathbf{x} \\
\mathbf{x} \\
\mathbf{x}\end{array}$ & $\begin{array}{c}101 \pm 8 \\
76 \pm 8 \\
122 \pm 12 \\
102 \pm 6 \\
116 \pm 21 \\
103 \pm 10 \\
87 \pm 17 \\
90 \pm 11 \\
210 \pm 15\end{array}$ & $\begin{array}{l}\mathbf{x} \\
\mathbf{x}\end{array}$ & \\
\hline III & 20 & $\begin{array}{l}\mathrm{x} \\
\mathrm{x}\end{array}$ & $\begin{array}{l}\mathbf{x} \\
\mathrm{x}\end{array}$ & $\begin{array}{l}144 \pm 14 \\
122 \pm 14 \\
132 \pm 21 \\
130 \pm 21\end{array}$ & & \\
\hline
\end{tabular}

*PN = homogenized extract of human sciatic nerve; $B P=$ specific brain protein.

+ Expressed as a per cent of four control cultures, \pm 2 SD.

protracted as that of any adult. The only patient to die in our series was a child. Half of those in category I were children.

In the second place, serial studies of peripheral nerve function are of use not only in documenting the course of the illness but possibly in a prognostic sense as well. Although serial studies of patients with idiopathic polyneuritis have been mentioned in the literature, detailed information on individual patients is not commonly cited. Several patterns of change are recorded. Lambert (1960) described the findings with stimulation of the median nerve in one patient, studied at 14,27 , and 81 days after the onset of the polyneuritis. Motor nerve conduction velocity was decreased only slightly. However, the amplitude of the muscle action potential response evoked by stimulation at the elbow was only $15.8 \%$ that of the response evoked by stimulation at the wrist. This type of change would correspond to our pattern one (Fig. 1). Recovery of the response to stimulation at the elbow began earlier in Lambert's patient and occurred more rapidly than recovery of the strength of voluntary contraction. Cerra and Johnson (1961) found that temporal dispersion of the muscle action potential preceded a decrease in motor nerve conduction velocity, but gave little data on their serial studies of 22 patients. Bannister and Sears (1962) looked for nerve action potentials after mechanical stimulation of a digital nerve, and after electrical stimulation of mixed nerve in median and ulnar nerves in one man, whose illness lasted 55 days.
Such potentials were found first at 50 days, when clinical recovery was almost complete. Distal motor latency was never less than 5 to $6 \mathrm{msec}$ in median nerve, in studies repeated until day 50 . IschTreussard, Buchheit, and Isch (1962) obtained three measurements of peroneal motor nerve conduction velocity in two adult patients, and two measurements in another. Studies were made from one to nine months after the onset of the illness. Looking at velocity and distal latency only, there was a lack of correlation between the most marked slowing and the most severe disease. In general, the velocity returned to normal, in a fashion parallel to but lagging behind clinical recovery. In a later paper, the same authors commented that these changes might be present from the start of the illness, or might take several weeks to appear (Isch, Isch-Treussard, Buchheit, Delgado, and Kircher, 1969). All patients studied by them did show slowing at some time, in nerve conduction velocity and distal latency in a parallel fashion. Humphrey (1964) did not observe a return of ulnar and peroneal nerve conduction velocities to normal until all deep tendon reflexes had recovered. Bergamini, Gandiglio, and Fra (1966) studied nerve conduction velocities in proximal and distal segments of ulnar (motor and mixed) and peroneal (motor) nerves in five patients. Studies were made within four weeks of the onset of the illness, and serially thereafter (at four, 12, 24, and 48 weeks). Two patients showed no significant change at any time, two patients had pronounced slowing in the 
axilla-to-elbow segment of ulnar nerve, and one patient had pronounced distal slowing in peroneal nerve only. Other segmental changes were observed. Slowing in the peroneal nerve was not as great as clinical signs would suggest. The severity of slowing paralleled rapidity of onset, rather than the degree of clinical involvement. Pronounced slowing (especially distally) was more common in the younger patients. The major alteration (when seen) was present by eight weeks, with recovery occurring before 16 weeks.

Twelve patients in this study were followed to clinical recovery with serial observation of peripheral nerve function. The parameters measured included modal motor nerve conduction velocity, distal motor latency, and amplitude of the evoked muscle action potential. When a marked slowing in nerve conduction velocity occurs with a change in both of the other parameters (Fig. 2), there is a strong correlation between the degree of slowing and the length of the illness (Fig. 3). The slowest conduction velocities were associated with the shortest clinical courses. From studies of guinea-pig sciatic nerve, Kaeser and Lambert (1962) concluded that a slight alteration in myelin structure could greatly impair nerve conduction velocity, while selective destruction of large motor neurones does not impair velocity in fibres that remain excitable. They observed a marked slowing of velocity (to $30 \%$ of normal) in diphtheritic polyneuritis but little slowing with Wallerian degeneration or thallium poisoning. A gradation of change, from mild segmental demyelination to severe axonal loss, is seen in peripheral nerves of patients who die of idiopathic polyneuritis (Asbury et al., 1969). Pattern two may reflect this gradation; pattern one does not exclude it. Whatever the explanation for the correlation between slowing and clinical course, it is important to consider this in assessing the benefit of any therapy for idiopathic polyneuritis.

Steroid therapy is based in part on the thesis that idiopathic polyneuritis is an immune disorder (Heller and DeJong, 1963). Although this thesis does not hold true for every patient (Drachman, Paterson, Berlin, and Roguska, 1970), it is an attractive one not only because of the pathological similarity between experimental allergic neuritis and idiopathic polyneuritis, but also in view of the demonstration of various immune phenomena in patients with idiopathic polyneuritis (Asbury et al., 1969). Circulating antibodies to peripheral nerve have been demonstrated in patients with idiopathic polyneuritis, but appear to be non-specific and not correlated with the clinical state of the patient (Melnick, 1963; Osuntokun, Prineas, and Field, 1966). Since such antibodies would be expected to comprise only a minute fraction of serum $\operatorname{IgG}$, it is not surprising that tota immunoglobulin levels-in our patients and in the literature (Dencker, Swahn, and Ursing, 1964? Wiederholt and Mulder, 1965)-show no striking? abnormalities. In vitro techniques show no differences between CSF protein in idiopathic polyneuritis and the proteins in serum and CSF from normal indi viduals (Ravn and Jensen, 1965).

The common denominator in pathological studies:of idiopathic polyneuritis is an inflammatorys demyelinative neuritis, marked by focal, perio vascular, lymphocytic infiltrates affecting any leveE of the peripheral nervous system (Asbury et al. 1969). Several lines of study have been used to sup $-\frac{\pi}{\Omega}$ port this evidence that immunity in idiopathices polyneuritis is cell-mediated. Buffy coat cells from? patients have been shown to destroy myelin in vitro (Arnason, Winkler, and Hadler, 1969). Mononuclear $\overrightarrow{\vec{\omega}}$ cells thought to be synthesizing deoxyribonucleico acid are found in the blood of patients with idiopathic polyneuritis, as well as a number of othero disorders (Cook and Dowling, 1968; Cook, Dowling $\omega$ and Whitaker 1970; Whitaker, Hirano, Cook, ander Dowling, 1970). Such cells are found more commonfigyo when the polyneuritis is acute, and in larger number in patients with the greatest morbidity (Cook et 9 , 음 1970).

Enhanced lymphocyte transformation on exposuree of cultures of lymphocytes from patients with idio-0 pathic polyneuritis to homologous peripheral nerie is recorded in the literature (Knowles, Saunder⿳亠口冋, Currie, Walton, and Field, 1969; Behan, Lamarche, Feldman, and Sheramata, 1970) and in this series. This method is thought to be a valid test in vitro foro the presence of cell-mediated immunity (Mills, 1966). In this series, however, it was not a phenomenono specific to peripheral nerve as an antigen (Table 4). $\frac{\text { \% }}{8}$ It did not occur regularly. This may derive in part@ from the observation that enhanced transformation $\vec{\circ}$ can be suppressed by steroids (Ono, Terayama, 3 Takaku, and Nakoo, 1968). Less transformation while on ACTH was observed in one patient. Two other patients, who showed no enhanced transformation, were on ACTH at the time of study Nevertheless, the two patients (Table 4; nos. 3 and 15 ) ${ }_{-}$ who showed the greatest amount of transformation 3 . had the longest clinical course (27 and 18 months, $\delta$ respectively). Unfortunately, the data are insufficient $₹$ to draw a correlation between the degree of activityo and the duration of disease. Thus we cannot say that the patients with the most severe disease haveo the most intense immune reaction, as others have claimed (Cook et al., 1970).

Plasma and urinary steroids were determined in the స్ laboratories of Dr. C. Charlton Mabry and Dr. William 
W. Winternitz. Serum and cerebrospinal fluid immunoglobulins were measured in the laboratory of Dr. Kenneth Gerson. Lymphocyte transformation was studied by Ira Fowler.

\section{REFERENCES}

Arnason, B. G., Winkler, G. F., and Hadler, N. M. (1969). Cell-mediated demyelination of peripheral nerve in tissue culture. Lab. Invest., 21, 1-10.

Asbury, A. K., Arnason, B. G., and Adams, R. D. (1969). The inflammatory lesion in idiopathic polyneuritis. Its role in pathogenesis. Medicine (Balt.), 48, 173-215.

Bannister, R. G., and Sears, T. A. (1962). The changes in nerve conduction in acute idiopathic polyneuritis. J. Neurol. Neurosurg. Psychiat., 25, 321-328.

Behan, P. O., Lamarche, J. B., Feldman, R. G., and Sheramata, W. A. (1970). Lymphocyte transformation in the Guillain-Barré syndrome. Lancet, 1, 421.

Bergamini, L., Gandiglio, G., and Fra, L. (1966). Motor and afferent nerve conduction in the Guillain-Barré-Strohl syndrome: a longitudinal study in five cases with different clinical features. Electromyography, 6, 205-232.

Cerra, D., and Johnson, E. W. (1961). Motor nerve conduction velocity in 'idiopathic' polyneuritis. Arch. phys. Med. Rehab., 42, 159-163.

Chambers, R., and MacDermot, V. (1957). Polyneuritis as a cause of 'amyotonia congenita'. Lancet, 1, 397-401.

Cook, S. D., and Dowling, P. C. (1968). Neurologic disorders associated with increased DNA synthesis in peripheral blood. Arch. Neurol. (Chic.), 19, 583-590.

Cook, S. D., Dowling, P. C., and Whitaker, J. N. (1970). The Guillain-Barré syndrome. Relationship of circulating immunocytes to disease activity. Arch. Neurol. (Chic.), 22, 470-474.

Dencker, S. J., Swahn, B., and Ursing, B. (1964). Protein pattern of cerebrospinal fluid during the course of acute polyradiculoneuropathy. Acta med. scand., 175, 499-506.

Drachman, D. A. Paterson, P. Y., Berlin, B. S., and Roguska, J. (1970). Immunosuppression and the GuillainBarré syndrome. Arch Neurol. (Chic.), 23, 385-393.

Guillain, G., Barré, J.-A., and Strohl, A. (1916). Sur un syndrome de radiculo-névrite avec hyperalbuminose du liquide céphalo-rachidien sans réaction cellulaire. Remarques sur les caractères cliniques et graphiques des réflexes tendineux. Bull. Soc. méd. Hôp. Paris, 40, 14621470.

Heller, G. L., and DeJong, R. N. (1963). Treatment of the Guillain-Barré syndrome. Use of corticotropin and glucocorticoids. Arch. Neurol. (Chic.), 8, 179-193.

Humphrey, J. G. (1964). Motor nerve conduction studies in the Landry-Guillain-Barré syndrome (acute ascending polyneuropathy). (Abstract.) Electroenceph. clin. Neurophysiol., 17, 96.

Isch, F., Isch-Treussard, C., Buchheit, F., Delgado, V., and Kircher, J. P. (1964). Measurement of conduction velocity of motor nerve fibres in polyneuritis and polyradiculoneuritis. (Abstract.) Electroenceph. clin. Neurophysiol., 16, 416.

Isch-Treussard, C., Buchheit, F., and Isch, F. (1962). Évolution de la vitesse de conduction nerveuse dans trois cas de polyradiculonévrite de Guillain-Barré. In Progress in Electromyography. Ed. by P. Pinelli, with the collaboration of F. Buchthal and F. Thiébaut. Electroenceph. clin. Neurophysiol., Suppl., 22, 51-54.
Kaeser, H. E., and Lambert, E. H. (1962). Nerve function studies in experimental polyneuritis. Electroenceph. clin. Neurophysiol., Suppl., 22, 29-35.

Knowles, M., Saunders, M., Currie, S., Walton, J. N., and Field, E. J. (1969). Preliminary communication. Lymphocyte transformation in the Guillain-Barré syndrome. Lancet, 2, 1168-1170.

Lambert, E. H. (1960). Neurophysiological techniques useful in the study of neuromuscular disorders. In Neuromuscular Disorders. Res. Publ. Ass. nerv. ment. Dis., 38, 247-273.

Landry, O. (1859). Note sur la paralysie ascendante aiguë. Gaz. hebd. Sci. med. Bordeaux, 6, 472-474.

Mancini, G., Carbonara, A. O., and Heremans, J. F. (1965). Immunochemical quantitation of antigens by single radial immunodiffusion. Int. J. Immunochem. 2, 235-254.

Markland, L. D., and Riley, H. D., Jr. (1967). The GuillainBarré syndrome in childhood. A comprehensive review, including observations on 19 additional cases. Clin. Pediat., 6, 162-170.

McQuillen, M. P., and Gorin, F. J. (1969). Serial ulnar nerve conduction velocity measurements in normal subjects. J. Neurol. Neurosurg. Psychiat., 32, 144-148.

Melnick, S. C. (1963). Thirty-eight cases of the GuillainBarré syndrome. An immunological study. Brit. med. J., 1, 368-373.

Mills, J. A. (1966). The immunologic significance of antigen induced lymphocyte transformation in vitro. J. Immunol. 97, 239-247.

Ono, T., Terayama, H., Takaku, F., and Nakao, K. (1968). Inhibitory effects of hydrocortisone upon the phytohemagglutinin-induced RNA-synthesis in human lymphocytes (BBA 95910). Biochim. Biophys. Acta, 161, 361-367.

Osler, L. D., and Sidell, A. D. (1960). The Guillain-Barré syndrome. The need for exact diagnostic criteria. New Engl. J. Med., 262, 964-969.

Osuntokun, G. O., Prineas, J., and Field, E. J. (1966). Immunological study of chronic polyneuropathies of undetermined cause. J. Neurol. Neurosurg. Psychiat., 29, 456-458.

Paulson, G. W. (1970). The Landry-Guillain-Barré-Strohl syndrome in childhood. Develop. Med. child Neurol., 12, 604-607.

Pleasure, D. E., Lovelace, R. E., and Duvoisin, R. C. (1968). The prognosis of acute polyradiculoneuritis. Neurology (Minneap.), 18, 1143-1148.

Posner, J. B., Ertel, N. H., Kossmann, R. J., and Scheinberg, L. C. (1967). Hyponatremia in acute polyneuropathy. Four cases with the syndrome of inappropriate secretion of antidiuretic hormone. Arch Neurol. (Chic.), 17, 530-541.

Ravn, H. (1967). The Landry-Guillain-Barré syndrome. A survey and a clinical report of 127 cases. Acta neurol. scand., 43, 1-64.

Ravn, H., and Jensen, K. (1965). Cerebrospinal fluid proteins in the Guillain-Barré syndrome. Immunological studies. Acta path. microbiol. scand., 65, 93-104.

Whitaker, J. N., Hirano, A., Cook, S. D., and Dowling, P. C. (1970). The ultrastructure of circulating immunocytes in Guillain-Barré syndrome. Neurology (Minneap.), 20, 765-770.

Wiederholt, W. C., and Mulder, D. W. (1965). Cerebrospinal fluid findings in the Landry-Guillain-Barré-Strohl syndrome. Neurology (Minneap.), 15, 184-187.

Wiederholt, C. W., Mulder, D. W., and Lambert, E. H. (1964). The Landry-Guillain-Barré-Strohl syndrome or polyradiculoneuropathy: historical review, report on 97 patients and present concepts. Proc. Mayo Clin., 39, 427-451. 